$$
-74-(940)
$$

使用洌にては 52 例中 $50 \%$ が 12.5 ケ月間 $25 \%$ が 12 ケ月聞生存している ${ }^{4}$ ，と報告している。及日比野 教授 ${ }^{5}$ 《生存月数の延長が文られ約 $10 \%$ の症例は生 存していて，寛解が可能で苦痛がさけられることを報 告している。

本例8㕛同様に人院直後より高熱となり，全身状態 堌悪したが繰返し輸血を行い，高度の貣血を支えつ小 6-MP 学使用したのであるが，網状赤血球の推移をみ るに入院值後は末棚南にて $1 \%$ であつたが，退院時に

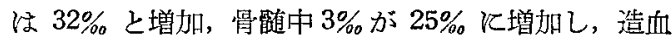
機能を活潑化するに最良の治療と思われ，急性の場合 に輸血忺くくへからざる処置と考えられる。次で各 種薬物療法であるが，本例に於ては 6-MP 妾使用し， 見るべき效果があり苦䇶を除去し，慢性化し得る事を 確めた。

結 論

1）2才の女呪化於ける Mikulicz 型を呈する亜白
日医大誌第 24 巻第 12 号 (1957)

血病を経験し6-MP を使用し宽解を見，病勢の慢性化 する事老得た。

2) 繰返し行う輸血柱造血機能を昂め必要欠くべか らざる治療法にて, 化学療法と共に充方施行すべきで ある事を経験した。

佁稿を終るに当り䅂始御指導を睗わり，御校閲をい ただいた恩師木由文夫教授，島田敏夫教授に謝意を捧 げ，標本作製御協力下さいました病理学教室河野教授 ，教室員の皆様に深謝を表します。

\section{参文 献}

1）赤崎兼㼁：綜合臨床 2, 1 号（昭 28）

2) 小宮悦造 : 綜合臨床 2, 1 号 (昭 28)

3）森・早川：小昌科診療 19，7 乓 (昭 31)

4) 前田伊三次郎：㟝療 9, 1 号 (昭 31)

5) 日比野進：最進医学 11，5号 (昭 31)

6) 岩川克信 : 小児f依满様涘患

\title{
業態婦の淋疾罹患に関する統計的観察
}

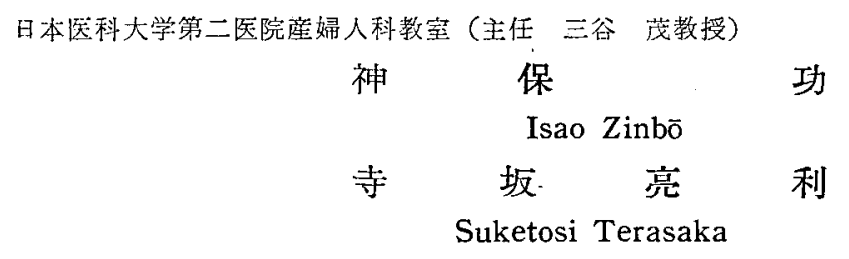

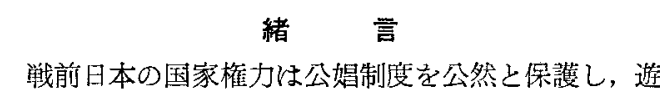
郈はさしろ風紀維持に必要な社会施設とされていた。 戦後上領政治のもとで男女同権を嵒う新繁法が制定 され，婦人の基本人権か强調された結果，公娼制度は 一底廃止されたわけではあるが，其れは表面的なるの で可等具体的な停止改革は諗められなかつた。昨年売 春防止法案が世諭の圧倒的支持を得て国会を通過し， 本年 4 月より更生保護規定の一部が既に実施され，来 年 4 月 1 日からは刑藅規定す発動され, 同法案が完全 奏施の運びとなるわけでかる。現在其の成行がー般の 注目の的となつている。しか乙同法案加性病の援隇 目的として発案されたるのではないが現在の如き性病 の減少が将来如何に変化する8のか注目に值する事柄 である。現在の所性病瞢延の最も大きな原因は夫婦外
性交である以上党春婦の性病に視線を向けざるを得な いのは勿論である。

ここに於て余等は横須賀市安浦町遊郭に於汸る業態 婦の淋疾䍀息の状態を年命及び学歴, 性経験, 営業, 性病予防, 麻薬賞醒剂, 月経, 家計等の角度加統計 的に䚁察し, 若干の知胃を得たので報告する次第です る。

\section{調查方 法}

ショートアンサー方式を採用し，プリントを印剧し て同じ問に対して表現を変えて重複せしめ，其の信頼 度の有無を確めて記録した。本調查に好意的に協力し た女性は 188 名である。

\section{調 查 成 績}

既往に於て罹患した性病の種類は延人員 199 名中淋 疾 111 名 $(56 \%)$, 梅毒 13 名 $(79 \%)$, 軟性下府 13 名 
$(7 \%)$, 第 4 性病 3 名 $(2 \% 6)$, 不明 26 名 $(14 \%)$, 䍜 患小きすの 33 名 (17\%) で淋疾が圧到的江多い。及 此の商売に入つて初めて性病檌患したすのは, 第 1 表の如く $67 \%$ 飞達していた。又此の商売に入つてか ら初めて性病儿䍜㭧与る迄の期間は, 第 2 表の如く 1 力月以内 $49 \% ， 1$ 力月以上 3 力月迄 $26 \%$ で，徉つて 3 力月以内で 75\% の者が罪患すると云う結果を示 した。

第 1 表この商壳と初回性病羅患との関係

\begin{tabular}{|c|c|c|}
\hline & 数 & $\%$ \\
\hline 离莣に入ってから羅虫 & 125 & 67 \\
\hline 商売に入る前に罹虫 & 8 & 4 \\
\hline 羅患せず & 30 & 16 \\
\hline 不明 & 25 & 13 \\
\hline 計 & 188 & 100 \\
\hline
\end{tabular}

第 2 表この商売と初回性病遙患运の期間

\begin{tabular}{|c|c|c|}
\hline & 数 & $\mathscr{\%}$ \\
\hline 1 力月以内 & 92 & 49 \\
\hline 1 力月以上 3 力月迄 & 49 & 26 \\
\hline 3 力月以上 6力月这 & 14 & 7 \\
\hline 6 力月以上 & 13 & 7 \\
\hline 霍患せず & 17 & 9 \\
\hline 不明 & 2 & 1 \\
\hline 計 & 188 & 99 \\
\hline
\end{tabular}

而して炤和 30 年 9 月より 10 月にかけての 1 カ月

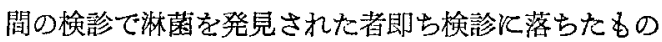
は 188 名中 68 名 (36\%) であつた。其の内 1 回落ち たものは 41 名 (21\%), 2 回落ちた子のは 23 名 (12 \%)，3回落ちたものは 3 名 (2\%)，4回はなく，5 回は 1 名 $(0.5 \%)$ であつた。この㺟睤状照を次の項目 により穓察して見た。

1) 年令及び学歴と權思状態

年令と淋疾程患との関保的 3 表の如く年令の若い 第 3 表 年令と淋涘醀患

\begin{tabular}{|c|c|c|c|c|c|}
\hline \multirow{2}{*}{ 命 } & 非 & 患 & 篧 & 患 & \multirow{2}{*}{ 計 } \\
\hline & 数 & $\% 6$ & 数 & $\%$ & \\
\hline $18 \sim 20$ & 18 & 46 & 21 & 54 & 39 \\
\hline $21 \sim 23$ & 40 & 66 & 21 & 34 & 61 \\
\hline $24 \sim 26$ & 28 & 62 & 17 & 38 & 45 \\
\hline 27以上 & 34 & 79 & 9 & 21 & 43 \\
\hline 計 & 120 & & 68 & & 188 \\
\hline
\end{tabular}

者程羅患率の高い結果を示した。年令的未経験かこの 㥞な結果を生じたるのと思われる。学歴との関係第; 4 表の如く学歴の高い者は概して䍜患率は高いと云う 結果となつた。

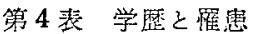

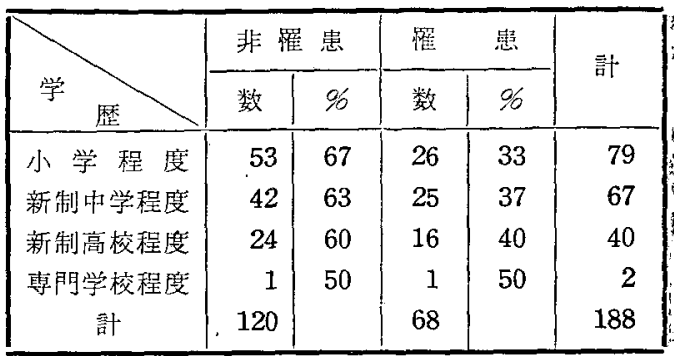

2) 性経験之羅勨状態

性経験即ら処女を失つた年令之結婚（同凄）経験の 有無の 2 項につき観察した。処女を失つた年令は， 18 才より 20 才迄の間が最る多く54\% を示した， 第 5 表の如く，此れと淋疾䍜患との関係仕認められな い。処女を失つた動機は結婚 $21 \%$ ，姃約及び恋愛 40 \%，商売 23\%，強㚣 5\%，好奇心 1\%，其他 $11 \%$ で あつた。結婚 (同棲) 経験の有無との関係は, 結婚 (同棲) 経験者は 188 名中 75 名 $(40 \%$ )，末坦者 113 第 5 表 処女を失つた年令を籊虫

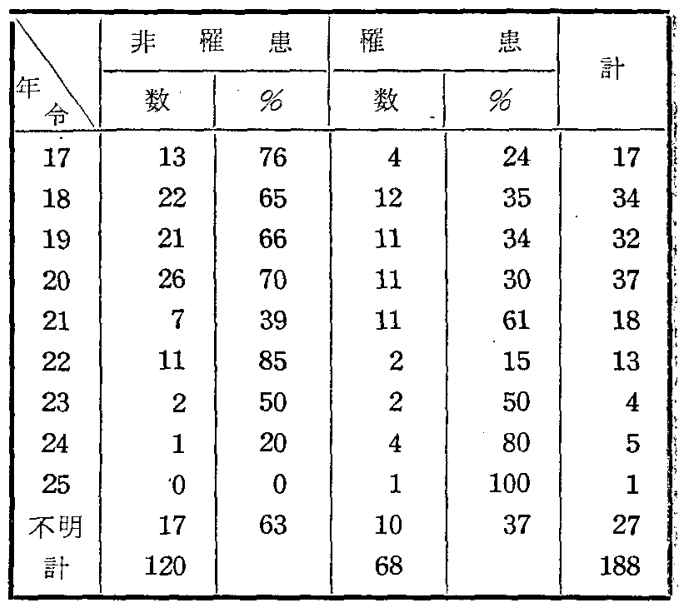

第 6 表 結婚（同淒）経俟の有無と羅虫

\begin{tabular}{|c|c|c|c|c|c|}
\hline & 非 & 腎 & & 䓌 & \multirow{2}{*}{ 計 } \\
\hline 結婚同 & 数 & 96 & 数 & 86 & \\
\hline 有 & 50 & 67 & 25 & 33 & 75 \\
\hline 無 & 70 & 62 & 43 & 38 & 113 \\
\hline 計 & 120 & & 68 & & 188 \\
\hline
\end{tabular}


名 $(60 \%)$ であつたが程悉状態は第 6 表の如く未婚者 に稍々多い傾向を示した。

3）営業之耑患状惎

営業の状態は，経験年数，なじみ客の種類及び接客 数の 3 種に分類した。

経駼年数に関しては第 7 表の如く年数の長い者程䍜 患率治明汃娍少していた。即ち経験年数の長い者程 性病淤する预防的関心が大であると云える。なじみ 第 7 表 経験年数之篗患

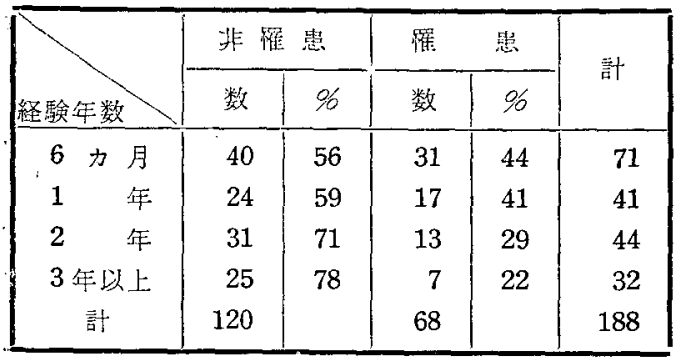

䈀8表なじみ客の種類と篗虫

\begin{tabular}{|c|c|c|c|c|c|c|}
\hline \multirow{2}{*}{ 種 類 } & & \multicolumn{2}{|c|}{ 非権 惢 } & \multicolumn{2}{|c|}{ 槛悥 } & \multirow{2}{*}{ 計 } \\
\hline & & 数 & $\%$ & 数 & 96 & \\
\hline 勤 & 人 & 74 & 68 & 35 & 32 & 109 \\
\hline 商 & 人 & 15 & 68 & 7 & 32 & 22 \\
\hline 自 & 隊 & 7 & 44 & 9 & 56 & 16 \\
\hline$I$. & 虽 & 11 & 69 & 5 & 31 & 16 \\
\hline 運 & 手 & 3 & 38 & 5 & 62 & 8 \\
\hline 学 & 生 & 3 & 50 & 3 & 50 & 6 \\
\hline 人 & 共 & 0 & 0 & 2 & 100 & 2 \\
\hline 莣 & 人 & 2 & 100 & 0 & 0 & 2 \\
\hline 僧 & 侶 & 0 & 0 & 1 & 100 & 1 \\
\hline 其 & 他 & 10 & 50 & 10 & 50 & 20 \\
\hline 不 & 明 & 12 & 86 & 2 & 14 & 14 \\
\hline な & L & 1 & 100 & 0 & 0 & 1 \\
\hline 計 & & 138 & & 79 & & 217 \\
\hline
\end{tabular}

第 9 表 1 日平均接客数と羅患

\begin{tabular}{|c|c|c|c|c|c|}
\hline & 非 & & & 忠 & \multirow{2}{*}{ 計 } \\
\hline 容数 & 数 & $\%$ & 数 & 96 & \\
\hline 1 人 & 7 & 64 & 4 & 36 & 11 \\
\hline $2 人$ & 18 & 75 & 6 & 25 & 24 \\
\hline $3 \wedge$ & 48 & 59 & 34 & 41 & 82 \\
\hline 4 人 & 19 & 59 & 13 & 41 & 32 \\
\hline 5 人 & 13 & 62 & 8 & 38 & 21 \\
\hline 不 明 & 15 & 83 & 3 & 17 & 18 \\
\hline 計 & 120 & & 68 & & 188 \\
\hline
\end{tabular}

客の種類との関係々第 8 表で示した如く自衛隊，運転 手，人夫をなじみ客とする者に羅息率が高いと云う結 果となつた。1 日平均接客数は 3 人が $43 \%$ で最も多 い。此れが榴息との関係は第 9 表の如く関連珄はない 様に思われた。

\section{4) 性病予防と羅患状䁅}

生病予防汇関しては彼女茎は極めて大きな䦥心を示 している。即ち殆ど大部の者 (97\%) 梳性交後直ちに

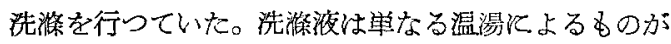
最も多い(59\%)。本項では客のコンドームの使用方法 と羅患との関係を追求して見た，第 10 表の如くコン ドーム使用率の藻い程慛㭧率は低いと云う当然の結果 老得た。

第 10 表 コンドームの使用方法と籊患

\begin{tabular}{|c|c|c|c|c|c|}
\hline & \multicolumn{2}{|c|}{ 非罹鳃 } & \multicolumn{2}{|c|}{ 榷＼cjkstart患 } & \multirow{2}{*}{ 部 } \\
\hline 方法 & 数 & 96 & 数 & $\%$ & \\
\hline 必ず使用 & 1 & 100 & 0 & 0 & 1 \\
\hline なるへく使用 & 25 & 71 & 10 & 29 & 35 \\
\hline 客飞よつて使用 & 73 & 66 & 38 & 34 & 111 \\
\hline 使用したりしなかつたり & 4 & 44 & 5 & 56 & 9 \\
\hline 使用しない & 15 & 56 & 12 & 44 & 27 \\
\hline 不明 & 2 & 40 & 3 & 60 & 5 \\
\hline 計 & 120 & & 68 & & 188 \\
\hline
\end{tabular}

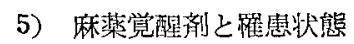

麻薬覚醒剂注謝の睡往あるものは 188 名中 22 名 (12\%) で, 其の種類は大部分 (91\%) は七ロポンであ り，他はモルヒネのみであつた。打ち始めた動機は人 の真似をした者 32\%，何となく打つてみた者 $18 \%$ ， 体が波れたため $14 \%$ ，他人からすすめられた者 $14 \%$ ， やけくそ 9\%，其他 15\% であつた。此れが槛必との 関係は第 11 表の如く特别の関連はない。

第 11 表 麻薬覚醒剂と簿患

\begin{tabular}{|c|c|c|c|c|c|}
\hline & \multicolumn{2}{|c|}{ 韭 霍 惥 } & 羅 & 患 & \multirow{2}{*}{ 尌 } \\
\hline 麻薬覚醒揢 & 数 & 96 & 数 & $\%$ & \\
\hline 打つたことなし & 99 & 64 & 55 & 36 & 154 \\
\hline 打つたことあり & 14 & 64 & 8 & 36 & 22 \\
\hline 不明 & 7 & 58 & 5 & 42 & 12 \\
\hline 計 & 120 & & 68 & & 188 \\
\hline
\end{tabular}

6) 月経と䍜患状態

月経時下腹痛，腰痛等の障碍を訴えた者江 76\%で, 変らない者 $18 \%$ ，不明 $6 \%$ であつた。及月経時佔を 休さ者 2796，休まない者 4996であつた。月経は順調 
第 12 表 月経と㦜墨

\begin{tabular}{|c|c|c|c|c|c|}
\hline & 非 & 患 & 䍜 & 邫 & \multirow{2}{*}{ 計 } \\
\hline 経 & 数 & $\%$ & 数 & 96 & \\
\hline 順 調 & 77 & 64 & 43 & 36 & 120 \\
\hline 不 順 & 36 & 65 & 19 & 35 & 55 \\
\hline 不 明 & 7 & 54 & 6 & 46 & 13 \\
\hline 計 & 120 & & 68 & & 188 \\
\hline
\end{tabular}

か否加の問に対する篗患の関係は第 12 表の如く特別 の関係は認められなかつた。

7) 家計と䍜急状態

彼女達の 1 力月間の小遗の消留㼭は最高 3 万円, 最 低 300 円で其の内6千～1万円迄 33 \% で最も多く, 1 干 3 干円 22\%，3 干以上～ 5 干円迄 $21 \% ， 1$ 万 円以上〜 3 万円迄 $12 \%$ の順であつた。この小遭消費 量と罹患との関係は特别望められなかつた。又親元な ぞへの仕送りは 188 名中 102 名 (54\%) が行つてい る。1 カ月最高 1 万 5 千円，最低 300 円で其の内 3 干 〜 F円の者が最も多く55\%であつた。此の仕送り の有無と躍㭧状態との関係第 13 表の如く仕送りし ている者の方が明かに犁患率は低いと云う結果を示し た。又仕送り金額と罹患との関係に就いて子検討して 見たが此れには特別の関係は認められなかつた。

第 13 翌 仕送りの有器と㘗患

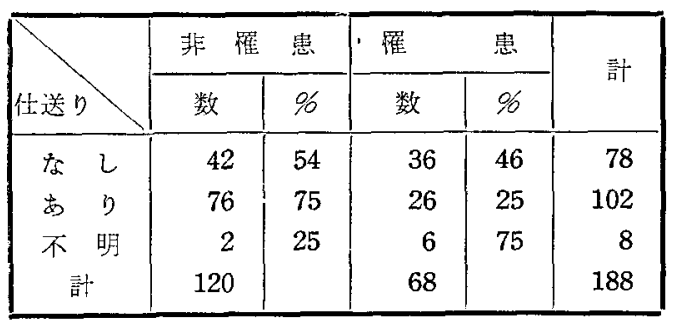

結語

余等は横須賀市安浦町遊郭の業態婦 188 名を対称と して, 淋疾罪患の状態を種々の角度より観察し, 次の 結果を得た。

1）年令の若い者程篗患率は高い。又学歴の低い者
は高い者より概して䍜患率は低い傾问にある。

2) 結婚 (同棲) 経験者は未婚者よりも熦患率は稍" 之低い。

3）経験年数の長い者愊い者より低率で, 又人 夫，運転手，自衛隊をなじみ客とする者は，高率であ る。

4）コンドームは使用度の高い者程䍜患率は低い。

5) 仕送りしている者は，乙ていない者より低率で ある。

6)接客数，赺女を失つた年令，林薬覚醒剂，月 経，小遗消費量，仕送り金額等と踓患率との間に特 別の関係は認められない。

稿を終るに臨夕御指導御校閱を賜つた恩師三谷教授 に深謝致します。又種々御教示を瀻いた横浜日赤産婦 人科医長三宅清平博士並びに本調查に協力せられた安 浦カフエー組合に対し敬意を表します。台本諭文の要 旨第 26 回日本産婦人科学会神祭川地方部会に於て 発表した。

\section{文献}

1) 榎本垻志雄 : 医界公唃 (21)，14（炤 24)

2)川島真他：公菜衛生 9，(1)，53（昭 26）

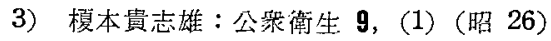

4) 雪吹 周: 臨林皮泌 6，(12），664（昭 27）

5) 田中 英：性病 37 (4)，161（昭 27）

6) 田中 英：性病 37 (4)，165(昭 27)

7) 市川篤二他：性病 38 (3)，63（昭 28）

8) 小原菊夫：性病予防研究 1 (1)，4（昭 28)

9）西㵯 明：日医大誌 21 (9)，870（昭 29）

10) 山田功也：皮性誌 64 (8), 517 (昭 29)

11) 高橋昭一他：北海道医学誌 $29(2), 714$ (昭29)

12) 高橋昭一他：北海道医学誌 $29(2) ， 706$ (昭29)

13) 并上幹次他：北海道医学誌 $29(2) ， 719$ (昭29)

14) 抻藤 実：性病 39 (1)，23(昭 29)

15) 春原千秋：遗伝 9(2)，24（昭 30)

16）增田圭喜：日医大誌 $23(2), 129$ (昭 31)

17) 加藤 实他：日医大誌 23 (2)，137 (昭 31)

18）尾立源二他：長崎綜合公柴衛生誌 $4(2) ， 14$ (昭 31)

19）村田文雄他：日産婦学会菒京地方部会報，6: (1)，33 (昭 32) 